\title{
Analisis Ancaman Orang Dalam dan Strategi Intrusi Sistem Proteksi Fisik Reaktor Nuklir dengan Pendekatan Stokastik
}

\section{Yanuar Ady Setiawan*}

Departemen Teknik Nuklir dan Teknik Fisika, Fakultas Teknik, Universitas Gadjah Mada, Yogyakarta 55281, Indonesia

\begin{tabular}{l}
\hline INFORMASI ARTIKEL \\
\hline Riwayat Artikel: \\
Diterima: \\
15 Juni 2019 \\
Diterima dalam bentuk revisi: \\
15 Januari 2020 \\
Disetujui: \\
29 April 2020 \\
\end{tabular}

Kata kunci:

Sistem proteksi fisik

Ancaman orang dalam

Strategi intrusi

Stokastik

EASI

\begin{abstract}
ABSTRAK
ANALISIS ANCAMAN ORANG DALAM DAN STRATEGI INTRUSI SISTEM PROTEKSI FISIK FASILITAS NUKLIR DENGAN PENDEKATAN STOKASTIK Model Estimate of Adversary Sequence Interruption (EASI) adalah sebuah model analisis satu jalur intrusi yang menghitung nilai probabilitas interupsi $\left(\mathrm{P}_{\mathrm{I}}\right)$ dari sebuah sistem proteksi fisik fasilitas tertentu untuk mencegah tindak pencurian ataupun sabotase dari musuh. Evaluasi sistem proteksi fisik diperlukan untuk memastikan sistem proteksi fisik mampu menanggulangi musuh dengan ragam atribut, karakteristik, dan kapabilitas serta kemungkinan adanya keterlibatan orang dalam. Makalah ini menunjukkan metode evaluasi sistem proteksi fisik menggunakan model EASI yang sudah dikembangkan dengan pendekatan stokastik, serta memperhitungkan variasi strategi intrusi musuh dan keterlibatan orang dalam. Sistem proteksi fisik pada studi kasus RDE di makalah ini rentan terhadap intervensi orang dalam, terutama intervensi pada fungsi deteksi. Namun, metode evaluasi sistem proteksi fisik kuantitatif yang dikembangkan di makalah ini memungkinkan perencanaan peningkatan performa sistem proteksi fisik hingga level yang meyakinkan publik dan pemangku kepentingan dengan melakukan modifikasi model sistem proteksi fisik yang dianalisis.
\end{abstract}

\begin{abstract}
ANALYSIS OF INSIDER THREAT AND INTRUSION STRATEGIES FOR PHYSICAL PROTECTION SYSTEM IN NUCLEAR FACILITY WITH STOCHASTIC APPROACH

The Estimate of Adversary Sequence Interruption (EASI) model is a single path analysis model to calculate the Probability of Interruption $\left(P_{1}\right)$ of a Physical Protection System (PPS) of a facility in preventing theft or sabotage act by the adversary. Evaluation of the physical protection system is needed to ensure it is capable to secure the facility against various type of adversary including the possibility of insider threat. This paper shows the method of evaluating physical protection system with consideration of insider threat and various intrusion strategies using EASI model with stochastic approach. By using the hypothetical RDE as a case study, the method shows that the physical protection system has a weakness in countering the act of an insider, especially when intervenes with detection function. However, the method presented in this paper allows performance improvement planning to meet the confidence level of public and stakeholders by modifying the physical protection system model being analysed.

Keywords: physical protection system, insider threat, intrusion strategy, stochastic, EASI
\end{abstract}

\section{PENDAHULUAN}

Material nuklir dan sumber radioaktif di dalam sebuah fasilitas nuklir bisa menjadi target yang menarik untuk operasi pencurian dan sabotase oleh kelompok kriminal tertentu, seperti organisasi teroris. Selain dampak buruk terkait paparan radiasi yang dapat merugikan masyarakat dan lingkungan sekitar, persepsi publik terkait insiden nuklir dan radiasi serta peran media massa dan media sosial berpotensi mengamplifikasi tindakan kelompok kriminal tersebut sehingga menimbulkan kepanikan di tengah masyarakat. Masifnya pemberitaan dan kepanikan masyarakat secara tidak langsung akan meningkatkan perhatian dan popularitas kelompok kriminal tersebut. Untuk mencegah hal-hal yang tidak diinginkan, baik itu dampak buruk ke masyarakat dan lingkungan maupun keuntungan bagi kelompok kriminal terkait, operator fasilitas nuklir perlu mendesain, memasang, dan menerapkan sebuah sistem keamanan, yakni sistem proteksi fisik, di fasilitas nuklir yang bersangkutan. Sistem proteksi fisik perlu dievaluasi pada tahap desain dan dievaluasi secara berkala.

Sistem proteksi fisik adalah sistem keamanan yang mengintegrasi peralatan, prosedur, dan personil untuk melindungi aset atau fasilitas dari tindakan pencurian, sabotase, atau tindakan jahat lainnya dari musuh. [1]. Sistem proteksi fisik memiliki tiga fungsi utama, yakni deteksi, hambatan, dan 
tanggapan, di mana ketiga fungsi tersebut perlu bekerja secara simultan dan bersifat komplemen satu sama lain untuk dapat menghentikan tindakan musuh saat menyusup dan menyerang fasilitas nuklir. Musuh-musuh yang perlu dihadapi fasilitas nuklir memiliki atribut, karakteristik, dan kapabilitas yang berbeda-beda [2] yang dijabarkan dalam dokumen Ancaman Dasar Desain (ADD) masing-masing negara yang bersangkutan. Sistem proteksi fisik harus dapat menghentikan tindakan kejahatan semua ragam tipe musuh yang dimandatkan oleh negara ke fasilitas nuklir yang bersangkutan.

Dalam sebuah pendekatan berbasis performa untuk mengevaluasi sistem proteksi fisik, efektivitas sistem $\left(\mathrm{P}_{\mathrm{E}}\right)$ digunakan untuk menilai bagaimana sistem proteksi fisik mencapai tingkat risiko (R) yang dapat diterima, seperti ditunjukkan pada Persamaan 1, di mana $\mathrm{P}_{\mathrm{A}}$ adalah nilai probabilitas serangan dan $\mathrm{C}$ adalah nilai konsekuensi yang terkait dengan keberhasilan serangan musuh. Nilai $P_{E}$ dalam formulasi risiko di Persamaan 1 dapat dikalkulasikan dengan memperhitungkan performa ketiga fungsi sistem proteksi fisik saat terjadi tindakan kejahatan oleh musuh. Kalkulasi tersebut diekspresikan di Persamaan 2, di mana $\mathrm{P}_{\mathrm{I}}$ adalah Probabilitas Interupsi dan $\mathrm{P}_{\mathrm{N}}$ adalah Probabilitas Netralisasi.

$$
R=P_{A} \times\left(1-P_{E}\right) \times C
$$

$$
P_{E}=P_{I} \times P_{N}
$$

Model Estimate of Adversary Sequence Interruption (EASI) adalah sebuah metode analisis satu jalur intrusi musuh untuk menghitung nilai $\mathrm{P}_{\mathrm{I}}$ dari sebuah sistem proteksi fisik [3]. Model ini telah digunakan di beberapa studi mengenai sistem proteksi fisik $[4,5,6]$. Analis perlu terlebih dahulu menentukan jalur intrusi musuh ke dalam fasilitas untuk mencapai target operasi, serta komponen deteksi dan hambatan sistem proteksi yang harus dihadapi musuh di sepanjang jalur tersebut untuk kemudian dianalisis dengan model EASI.

Makalah sebelumnya [7] telah menunjukkan penerapan metode monte carlo sebagai pendekatan stokastik untuk memperhitungkan faktor ketidakpastian fungsi hambatan sistem proteksi serta menghasilkan nilai ketidakpastian pada hasil $\mathrm{P}_{\mathrm{I}}$ yang tidak ada pada model EASI standar. Namun, keberadaan ancaman orang dalam belum diperhitungkan di makalah tersebut.

Ancaman orang dalam patut diperhitungkan dalam desain dan evaluasi sistem proteksi fisik. Orang dalam boleh jadi memiliki pengetahuan, akses, dan wewenang terhadap sistem proteksi fisik yang dapat disalahgunakan untuk membantu musuh dari luar seperti ditunjukkan di sebuah studi [8,9].

Tujuan studi yang disampaikan dalam makalah ini adalah kombinasi beberapa studi $[7,8,9]$, yakni evaluasi sistem proteksi fisik fasilitas nuklir dengan menggunakan model EASI yang sudah dikembangkan dengan pendekatan stokastik serta memperhitungkan variasi strategi intrusi musuh dari luar dan variasi keterlibatan orang dalam membantu penyusupan dan penyerangan musuh dari luar.

Metode yang dikembangkan ini dapat dimanfaatkan untuk mengevaluasi serta meningkatkan performa sistem proteksi fisik dalam mengamankan reaktor nuklir terhadap ancaman orang luar dan orang dalam secara kuantitatif hingga level yang meyakinkan publik dan berbagai pemangku kepentingan.

\section{POKOK BAHASAN}

2.1. Adversary Sequence Diagram (ASD) Reaktor Daya Eksperimental (RDE) Hipotetis

Fasilitas nuklir hipotetis dengan sistem proteksi fisik untuk studi analisis di makalah ini dibentuk dengan mengacu tampang lintang dan area Reaktor Daya Eksperimental (RDE) yang disampaikan secara terbatas di referensi [10]. RDE merupakan reaktor nuklir bertipe HTGR (High Temperature Gas-cooled Reactor) yang hendak dibangun di Kawasan Puspiptek, Serpong. Teknologi reaktor dengan daya 10 MWt, bahan bakar nuklir jenis pebble pada teras grafit, pendingin helium, dan moderator grafit tersebut memungkinkan aplikasi kogenerasi pemasok panas untuk kebutuhan industri.

Angka-angka performa komponen fungsi deteksi dan hambatan didapatkan dari literatur [11]. Angka-angka tersebut didapatkan dengan mengasumsikan bahwa musuh eksternal adalah kelompok kriminal/teroris berjumlah 3-4 orang yang menggunakan perkakas manual (hand tools) dan elektrik ( $p$ ower tools), memiliki bahan 


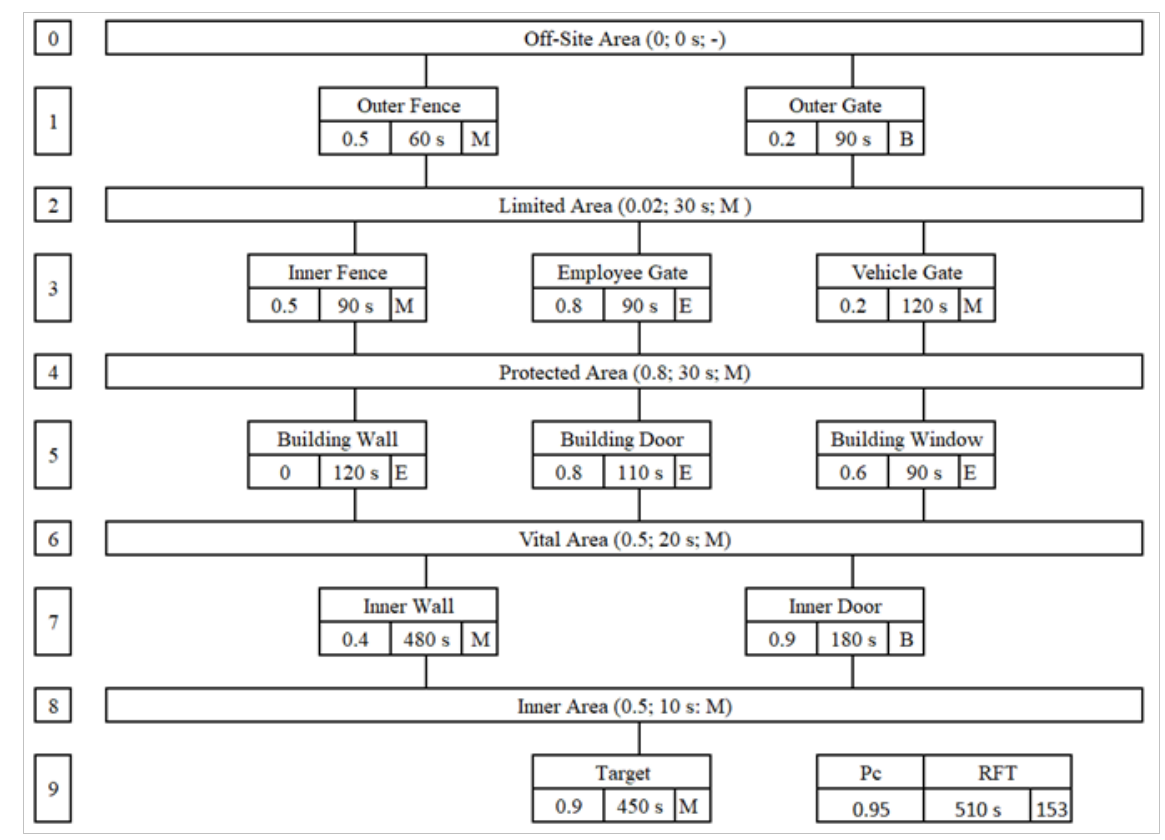

Gambar 1. Model Adversary Sequence Diagram (ASD) Fasilitas Nuklir Hipotetis RDE

peledak dalam jumlah terbatas, serta memiliki informasi mengenai denah fasilitas dan sistem proteksi fisik dari orang dalam.

Gambar 1 menunjukkan Adversary Sequence Diagram (ASD) dari fasilitas nuklir hipotetis RDE yang digunakan di studi ini, ASD tersebut memperlihatkan lapisan-lapisan sistem proteksi fisik (limited area, protected area, vital area, inner area) serta setiap kemungkinan jalur yang bisa dilewati oleh musuh di tiap lapisan, dari lapisan paling luar di bagian atas gambar hingga lapisan paling dalam di bagian bawah gambar. Setiap elemen di ASD memiliki 3 atribut, yakni informasi mengenai probabilitas deteksi $\left(\mathrm{P}_{\mathrm{D}}\right)$, waktu hambatan $\left(\mathrm{t}_{\mathrm{d}}\right)$ yang harus dilalui musuh, serta lokasi deteksi di elemen tersebut $(\mathrm{B}=$ Beginning untuk deteksi di awal proses hambatan, $\mathrm{M}=$ Middle untuk deteksi di tengah proses hambatan, $\mathrm{E}=$ End untuk deteksi di akhir proses hambatan). Sebagai contoh di lapisan 1, terdapat pagar luar (Outer Fence) dengan $P_{D}=0,5 ; t_{d}=60$ detik; dan lokasi deteksi M. Lokasi tersebut mengindikasikan bahwa nilai riil waktu hambatan elemen tersebut adalah setengah dari 60 detik, karena secara praktis musuh hanya perlu menghabiskan kurang lebih 30 detik setelah terdeteksi di tengah proses melewati hambatan 60 detik tersebut. Kotak di bagian bawah kanan ASD merupakan informasi mengenai performa komunikasi dan kesigapan tim tanggap darurat (fungsi tanggapan) sistem proteksi fisik, yakni probabilitas ketepatan komunikasi informasi dari penilai sinyal deteksi ke tim tanggap darurat $\left(\mathrm{P}_{\mathrm{C}}\right)$ sebesar 0,95 dab waktu respon tim tanggap darurat untuk menginterupsi musuh $(\mathrm{RFT}=$ response force time $)$ sebesar $510 \pm 153$ detik.

Setidaknya terdapat 3 pendekatan strategi yang bisa diterapkan oleh musuh untuk menyusup/menyerang fasilitas [7]. Ketiga prinsip tersebut bisa dipakai analis dalam memprediksi jalur intrusi musuh ke dalam fasilitas. Strategi pertama adalah strategi sembunyi di mana musuh memilih untuk meminimalisir kemunginan terdeteksi oleh sistem proteksi fisik sehingga memilih jalur intrusi dengan nilai $P_{D}$ terkecil di setiap lapisan proteksi. Strategi kedua adalah strategi bergegas di mana musuh berusaha secepat mungkin dalam melakukan penyerangan masuk ke dalam fasiitas sehingga memilih jalur intrusi dengan nilai $t_{d}$ terkecil di setiap lapisan proteksi. Strategi ketiga adalah strategi gabungan di mana musuh mengombinasikan strategi sembunyi (minimalisasi $\mathrm{P}_{\mathrm{D}}$ ) hingga mencapai Critical Detection Point (CDP), kemudian menggunakan strategi bergegas (minimalisasi $t_{d}$ ) setelah CDP untuk mencapai target dan menyelesaikan tindak kejahatan. CDP adalah titik deteksi terakhir di jalur intrusi di mana sistem proteksi fisik masih memiliki akumulasi waktu hambatan yang cukup bagi tim tanggap darurat datang dan menghentikan musuh (akumulasi $t_{d}$ tersisa $>=$ RFT). Prinsip strategi gabungan tersebut dipercaya sebagai strategi 
terbaik bagi musuh melakukan intrusi sedalam mungkin, sehingga prinsip tersebut banyak dipakai untuk menganalisis ASD untuk mendapatkan jalur intrusi paling rentan (MVP = Most Vulnerable Path) $[12,13,14]$.

\subsection{Kalkulasi Estimate of Adversary Sequence Interruption (Easi)}

Model EASI menggunakan Persamaan 3 untuk mengalkulasi nilai $\mathrm{P}_{\mathrm{I}}$ suatu jalur intrusi musuh yang dianalisis [3], di mana $\mathrm{P}_{(\mathrm{R} \mid \mathrm{Ai})}$ adalah probabilitas kondisional kedatangan tim tanggap darurat masih dapat menghentikan musuh jika dan hanya jika alarm intrusi dipicu oleh komponen fungsi deteksi di lapisan tertentu (lapisan ke-i), kemudian diverifikasi, dan dikomunikasikan dengan tepat ke tim tanggap darurat. Nilai $\mathrm{P}_{(\mathrm{R} \mid \mathrm{Ai})}$ untuk tiap lapisan proteksi pada suatu jalur intrusi yang dianalisis, didapatkan dengan mengakumulasi probability density function (PDF) dari $-\infty$ hingga $z$-score lapisan proteksi lokasi deteksi ( $z_{\mathrm{i}}$ untuk lapisan ke-i) pada distribusi normal yang dibentuk oleh nilai rerata dan eror waktu respon tim tanggap darurat $\left(\mathrm{RFT} \pm \sigma_{\mathrm{RFT}}\right)$.

Nilai $z$-score pada sebuah lapisan proteksi $\left(\mathrm{z}_{\mathrm{i}}\right)$ bergantung pada berapa banyaknya waktu hambatan riil tersisa yang masih perlu ditempuh musuh untuk menyelesaikan tindakan kejahatan dari lokasi spesifik deteksi (B, M, atau E) lapisan proteksi ke-i hingga akhir intrusi. Selain memperlihatkan persamaan untuk kalkulasi $z^{-}$ score lapisan $\mathrm{ke}-\mathrm{i}$, persamaan tersebut menunjukkan bahwa faktor ketidakpastian waktu hambatan dan waktu respon tim tanggap darurat telah diperhitungkan model EASI.

Persamaan 3 untuk menghitung $P_{I}$ mengakumulasi probabilitas musuh terdeteksi untuk pertama kali di lapisan proteksi ke-i, probabilitas informasi deteksi dikomunikasikan dengan tepat, dan probabilitas tim tanggap darurat datang tepat waktu karena deteksi di lapisan proteksi $\mathrm{ke}-\mathrm{i}$ tersebut. Akumulasi tersebut dilakukan untuk setiap lapisan proteksi jalur intrusi yang dianalisis oleh model EASI, dari awal hingga akhir.

$$
\begin{aligned}
P_{I}= & P_{\left(D_{1}\right)} \times P_{\left(C_{1}\right)} \times P_{\left(R \mid A_{1}\right)} \\
& +\left[\sum_{i=2}^{n} P_{\left(D_{i}\right)} \times P_{\left(C_{i}\right)} \times P_{\left(R \mid A_{i}\right)} \times \prod_{i=1}^{i-1}\left(1-P_{\left(D_{i}\right)}\right)\right]
\end{aligned}
$$

$$
z_{i}=\frac{x-\mu}{\sigma}=\frac{\text { nilai kumulatif riil } t_{d_{i}}-R F T}{\sqrt{\text { nilai kumulatif riil } \sigma^{2} d_{i}+\sigma_{R F T}^{2}}}
$$

\subsection{Ancaman Orang Dalam}

Istilah orang dalam pada keamanan nuklir ditujukan untuk musuh yang memiliki akses resmi ke fasilitas nuklir, operasional fasilitas, ataupun informasi penting [15]. Orang dalam tersebut dapat memiliki satu atau lebih atribut yang dapat disalahgunakan, yakni pengetahuan, akses, dan wewenang. Orang dalam dapat memiliki motivasi yang berbeda, antara lain karena masalah personal atau ideologi, untuk mendapat keuntungan finansial, karena masalah psikis, atau bahkan karena dipaksa musuh melalui pemerasan untuk melakukan hal tersebut. Orang dalam tersebut bisa bersifat pasif, sebatas memberikan informasi ke musuh, ataupun secara aktif membantu saat musuh menyusup/menyerang, seperti membukakan pintu-pintu, melawan personil kemanan, atau menyabotase perangkat sistem proteksi fisik.

\section{METODOLOGI}

Studi evaluasi sistem proteksi fisik ini dilakukan dengan menerapkan prinsip (1) strategi sembunyi, (2) strategi bergegas, dan (3) strategi gabungan dalam menganalisis ASD fasilitas nuklir hipotetis RDE. Untuk setiap jalur intrusi yang dibentuk dengan menerapkan ketiga strategi tersebut, diasumsikan terdapat satu orang dalam yang melakukan intervensi terhadap fungsi suatu elemen dalam jalur intrusi tersebut, seperti (1) intervensi komponen deteksi $\left(\mathrm{P}_{\mathrm{D}}=0\right)$; (2) intervensi komponen hambatan $\left(t_{d}=0\right.$ detik $)$; (3) intervensi komponen deteksi dan hambatan sekaligus ( $P_{D}=0$ dan $t_{d}=0$ detik). Pemodelan ini dilakukan analis secara manual sehingga perlu dicermati elemen lapisan proteksi mana yang komponen deteksi atau hambatannya dapat diintervensi oleh orang dalam tersebut.

Jalur-jalur intrusi tersebut, dengan variasi strategi intrusi serta variasi keterlibatan orang dalam, kemudian disimulasikan menggunakan program perhitungan EASI yang dikembangkan dengan pendekatan stokastik [7]. 
Tabel 1. Jalur Intrusi Musuh Dari Luar Ke Dalam Fasilitas Nuklir Hipotetis RDE

\begin{tabular}{|c|c|c|c|c|c|c|c|c|c|c|c|c|c|c|c|}
\hline & \multicolumn{5}{|c|}{ Strategi Sembunyi } & \multicolumn{5}{|c|}{ Strategi Bergegas } & \multicolumn{5}{|c|}{ Strategi Gabungan } \\
\hline $\mathrm{i}$ & $\mathrm{PD}_{\mathrm{D}}$ & $\sigma_{D}$ & $\mathrm{~L}$ & $t_{d}$ & $\sigma_{\mathrm{d}}$ & $P_{D}$ & $\sigma_{D}$ & $\mathrm{~L}$ & $t_{d}$ & $\sigma_{\mathrm{d}}$ & $P_{D}$ & $\sigma_{D}$ & $\mathrm{~L}$ & $t_{d}$ & $\sigma_{d}$ \\
\hline 1 & 0.2 & 0.02 & $\mathrm{~B}$ & 90 & 27 & 0.5 & 0.05 & $\mathrm{M}$ & 60 & 18 & 0.2 & 0.02 & B & 90 & 27 \\
\hline 2 & 0.02 & 0.002 & M & 30 & 9 & 0.02 & 0.002 & M & 30 & 9 & 0.02 & 0.002 & M & 30 & 9 \\
\hline 3 & 0.2 & 0.02 & M & 120 & 36 & 0.5 & 0.05 & M & 90 & 27 & 0.2 & 0.02 & M & 120 & 36 \\
\hline 4 & 0.8 & 0.08 & M & 30 & 9 & 0.8 & 0.08 & M & 30 & 9 & 0.8 & 0.08 & M & 30 & 9 \\
\hline 5 & 0 & 0 & $\mathrm{E}$ & 120 & 36 & 0.6 & 0.06 & $\mathrm{E}$ & 90 & 27 & 0 & 0 & $\mathrm{E}$ & 120 & 36 \\
\hline 6 & 0.5 & 0.05 & M & 20 & 6 & 0.5 & 0.05 & M & 20 & 6 & 0.5 & 0.05 & M & 20 & 6 \\
\hline 7 & 0.4 & 0.04 & M & 480 & 144 & 0.9 & 0.09 & B & 180 & 54 & 0.9 & 0.09 & B & 180 & 54 \\
\hline 8 & 0.5 & 0.05 & M & 10 & 3 & 0.5 & 0.05 & M & 10 & 3 & 0.5 & 0.05 & M & 10 & 3 \\
\hline 9 & 0.9 & 0.09 & M & 450 & 135 & 0.9 & 0.09 & M & 450 & 135 & 0.9 & 0.09 & M & 450 & 135 \\
\hline
\end{tabular}

Simulasi tersebut menghasilkan distribusi nilai $\mathrm{P}_{\mathrm{I}}$ dari 10.000 percobaan perhitungan, sehingga nilai $\mathrm{P}_{\mathrm{I}}$ dan ketidakpastian distribusinya bisa didapatkan.

\section{HASIL DAN PEMBAHASAN}

Penerapan strategi intrusi dalam menganalisis ASD akan menghasilkan spesifikasi jalur intrusi yang siap untuk dianalisis dengan menggunakan model EASI. Tabel 1 menunjukkan tiga jalur intrusi hasil analisis ASD fasilitas nuklir hipotetis RDE. Notasi i pada tabel tersebut menunjukkan nomor lapisan proteksi ke-i. Notasi L pada tabel 1 menunjukkan lokasi spesifik deteksi pada elemen lapisan proteksi (B, M, atau E).

Gambar 2, 3, dan 4 menunjukkan distribusi nilai $\mathrm{P}_{\mathrm{I}}$ ketiga jalur intrusi Tabel 1. Dari hasil simulasi tersebut dapat dilihat bahwa jalur intrusi dari strategi gabungan memilki nilai $P_{I}$ yang paling rendah. Hal ini berarti bahwa tanpa bantuan orang dalam, musuh dari luar harus mengombinasikan dua strategi berbeda dengan memperhitungkan CDP dari jalur intrusi untuk dapat meminimalisasi peluang interupsi tim tanggap darurat jadi sekecil mungkin. Dari ketiga distribusi di Gambar 2, 3, dan 4 tidak didapatkan nilai $\mathrm{P}_{\mathrm{I}}$ yang lebih kecil dari 0.8, angka yang dipercaya adalah batas minimal $P_{I}$ dari sistem proteksi fisik. Nilai rerata dan eror simulasi ketiga jalur tersebut ada di Tabel 2.

Nilai rerata dan eror pada Tabel 2 juga menunjukkan bahwa untuk jalur intrusi dengan strategi sembunyi, penurunan terbesar nilai $\mathrm{P}_{\mathrm{I}}$ terjadi saat orang dalam mengintervensi komponen deteksi $\left(\mathrm{P}_{\mathrm{D}}=0\right)$, dalam hal ini adalah komponen deteksi pada lapisan ke-4. Untuk jalur intrusi ini, intervensi komponen hambatan $\left(t_{d}=0\right)$ hanya dapat dilakukan pada lapisan proteksi ke-3 (Vehicle Gate). Tambahan intervensi deteksi $\left(P_{D}=0\right.$ dan $\left.t_{d}=0\right)$ pada elemen proteksi ke-3 tidak memberi dampak signifikan. Gambar 5 memperlihatkan distribusi nilai $P_{I}$ di mana tidak ada nilai $P_{I}$ yang kurang dari 0,7 .

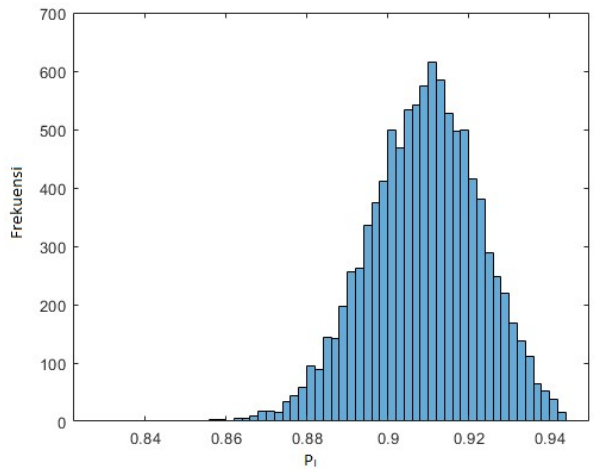

Gambar 2. Distribusi Nilai PI Jalur Intrusi Strategi Sembunyi tanpa Orang Dalam

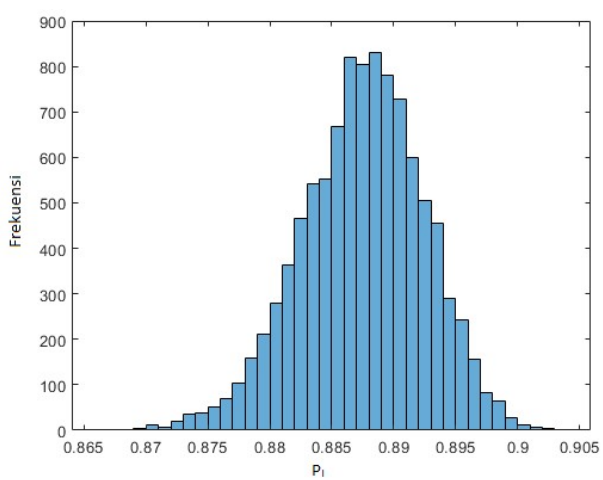

Gambar 3. Distribusi Nilai PI Jalur Intrusi Strategi Bergegas tanpa Orang Dalam

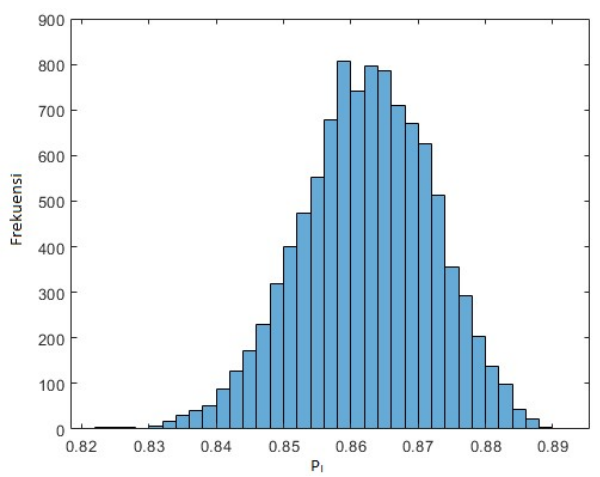

Gambar 4. Distribusi Nilai PI Jalur Intrusi Strategi Gabungan tanpa Orang Dalam 
Tabel 2. Nilai $\mathrm{P}_{\mathrm{I}}$ Hasil Simulasi Model EASI dengan Pendekatan Stokastik

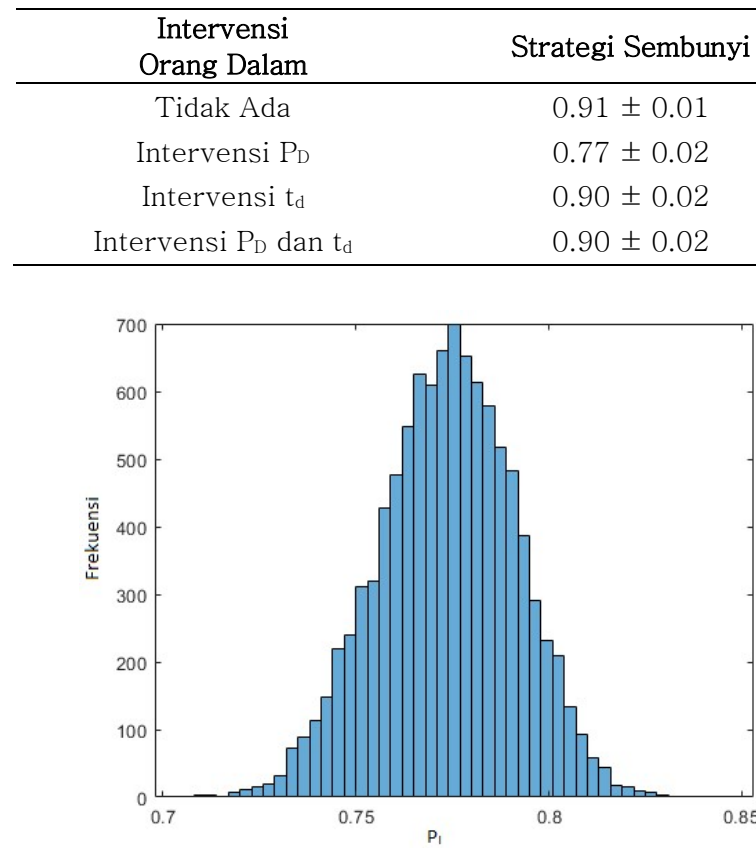

Gambar 5. Distribusi Nilai $P_{I}$ Jalur Intrusi Strategi Sembunyi dengan Bantuan Intervensi $P_{D}$ dari Orang Dalam

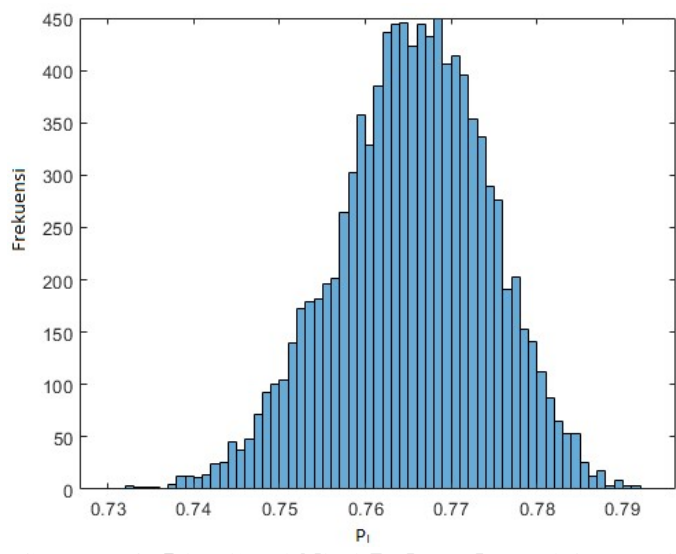

Gambar 6. Distribusi Nilai $P_{I}$ Jalur Intrusi Strategi Gabungan dengan Bantuan Intervensi $P_{D}$ dari Orang Dalam

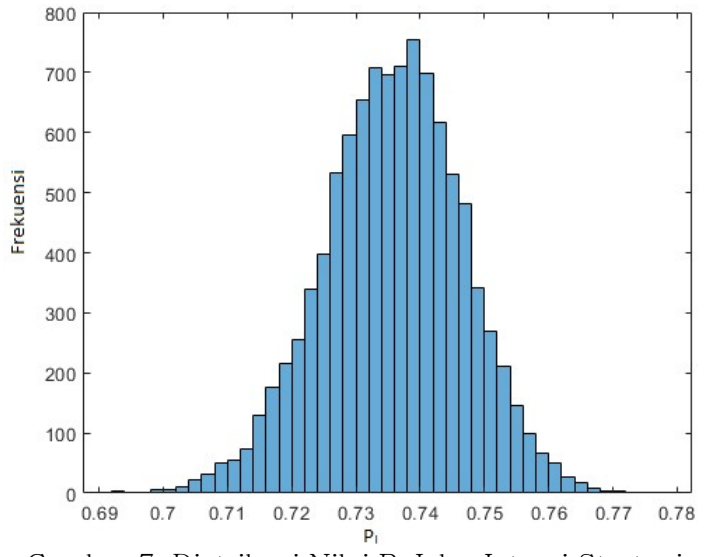

Gambar 7. Distribusi Nilai $P_{I}$ Jalur Intrusi Strategi Bergegas dengan Bantuan Intervensi td Dari Orang Dalam

Strategi Bergegas Strategi Gabungan

$\begin{array}{ll}0.89 \pm 0.01 & 0.86 \pm 0.01 \\ 0.85 \pm 0.01 & 0.77 \pm 0.01 \\ 0.74 \pm 0.01 & 0.69 \pm 0.02 \\ 0.73 \pm 0.01 & 0.68 \pm 0.02\end{array}$

$0.73+0.01$

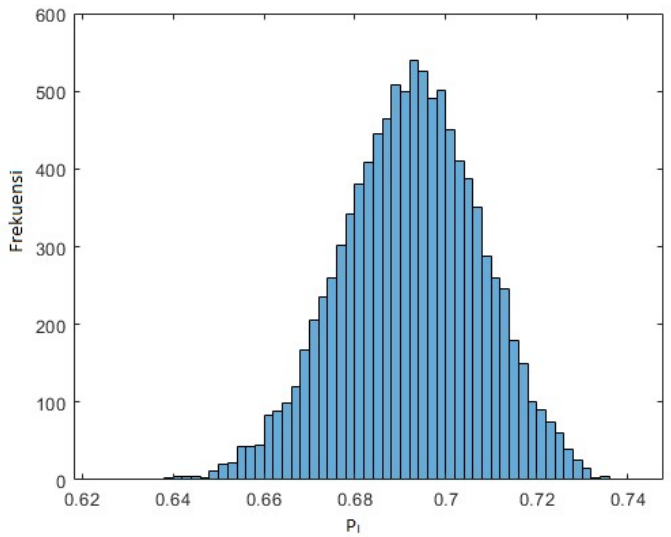

Gambar 8. Distribusi Nilai PI Jalur Intrusi Strategi Gabungan dengan Bantuan Intervensi $t_{d}$ dari Orang Dalam

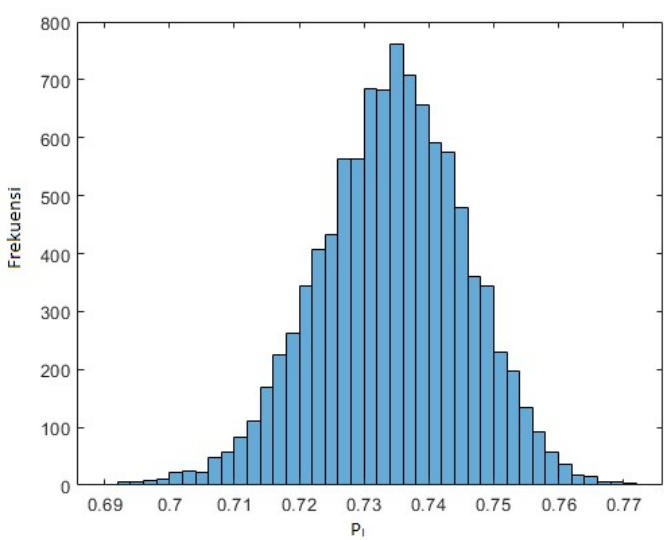

Gambar 9. Distribusi Nilai $P_{I}$ Jalur Intrusi Strategi Bergegas dengan Bantuan Intervensi $P_{D}$ dan $t_{d}$ dari Orang Dalam

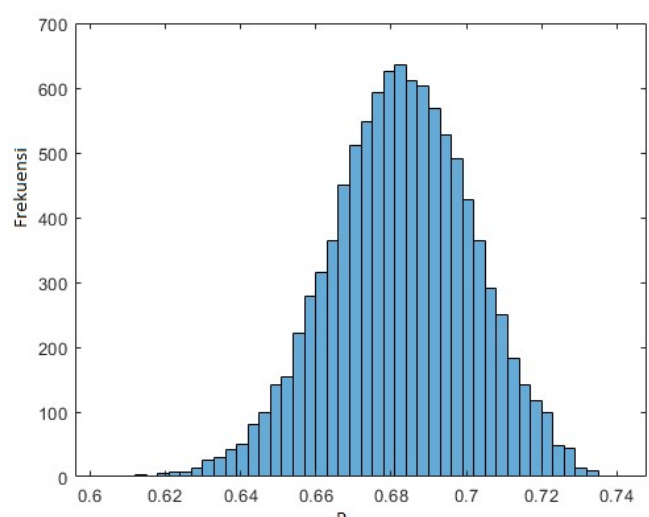

Gambar 10. Distribusi Nilai $P_{I}$ Jalur Intrusi Strategi Gabungan dengan Bantuan Intervensi $P_{D}$ dan $t_{d}$ dari Orang Dalam 
Untuk jalur intrusi dengan strategi bergegas, intervensi hambatan hanya dapat dilakukan pada lapisan proteksi $\mathrm{ke}^{-7}$, yakni pintu ke inner area (Inner Door). Intervensi hambatan memiliki dampak yang lebih signifikan daripada intervensi deteksi di jalur intrusi ini. Intervensi deteksi paling signifikan apabila dilakukan pada lapisan proteksi ke-4. Yang patut menjadi perhatian di sini adalah Gambar 7 dan 9 memperlihatkan adanya nilai $P_{I}$ hasil perhitungan simulasi kurang dari 0,7 walaupun nilai rerata dan erornya di atas 0,7.

Jalur intrusi dengan strategi gabungan memiliki karakter yang mirip dengan strategi bergegas. Intervensi deteksi paling signifikan di lapisan proteksi ke-4, intervensi hambatan paling signifikan di lapisan proteksi ke-7, tambahan intervensi deteksi setelah intervensi pada lapisan proteksi ke-7 tidak berdampak signifikan. Gambar 6, 8, dan 10 memperlihatkan distribusi nilai $\mathrm{P}_{\mathrm{I}}$ jalur intrusi strategi gabungan dengan variasi intervensi.

\section{KESIMPULAN}

Makalah ini menunjukkan metode evaluasi sistem proteksi fisik menggunakan model EASI yang sudah dikembangkan dengan pendekatan stokastik, serta memperhitungkan variasi strategi intrusi musuh dan keterlibatan orang dalam. Tanpa bantuan aktif orang dalam, musuh harus menggunakan strategi gabungan untuk meminimalisasi peluang interupsi tim tanggap darurat menjadi sekecil mungkin. Namun, ternyata sistem proteksi fisik fasilitas nuklir tersebut rentan terhadap ancaman orang dalam, terutama intervensi fungsi hambatan. Dengan modifikasi model yang dianalisis dengan metode ini, peningkatan desain sistem proteksi fisik RDE dalam menghadapi berbagai ancaman hingga level $\mathrm{P}_{\mathrm{I}}$ yang meyakinkan publik dan pemangku kepentingan dapat direncanakan.

\section{UCAPAN TERIMA KASIH}

Ucapan terima kasih ditujukan kepada Prof. Sunil Chirayath dan Dr. Evans Kitcher dari Texas A\&M University untuk bimbingan dan bantuannya selama penulis melaksanakan riset terkait hal ini, serta Lembaga Pengelola Dana Pendidikan (LPDP) yang mendanai riset metode evaluasi ini dan studi S2 Penulis (2016-2018).

\section{DAFTAR ACUAN}

[1]. MARY LYNN GARCIA. 2001. The Design and Evaluation of Physical Protection System. $1^{\text {st }}$ Edition. ButterworthHeinemann. Burlington, MA, USA: Elsevier Science, 111.

[2]. "Development, Use and Maintenance of the Design Basis Threat”. IAEA, Vienna, Austria, Nuclear Security Series No. 10, 2009, 3-13.

[3]. BENNET H. A., "EASI - An Evaluation Method for Physical Security System", Nuclear Materials Management, Vol. 6, No. 3, 1977, 371-379.

[4]. WADOUD A.A., ADAIL A.S., SALEH A.A., "Physical Protection Evaluation Process for Nuclear Facility via Sabotage Scenarios”, Alexandria Engineering Journal, Vol. 57, No. 2, June 2018, 831-839.

[5]. OYEYINKA O.D., DIM L.A., ECHETA M.C., KUYE A.O., "Determination of System Effectiveness for Physical Protection System of a Nuclear Energy Centre”, Science and Technology, Vol. 4, No. 2, 2014, 9-16.

[6]. BAKR W.F., HAMED A.A., "Upgrading the Physical Protection System (PPS) to Improve the Response to Radiological Emergencies Involving Malevolent Action”. Journal of Physical Security, Vol. 3, No.1, June 2009, 9- 16 .

[7]. SETIAWAN, Y., CHIRAYATH, S., "Stochastic Approach in Single Path Analysis of Adverary's Intrusion Strategies in Physical Protecton System (PPS) Effectiveness Evaluation". 59 ${ }^{\text {th }}$ INMM Annual Meeting Proceedings, Baltimore, USA, July 2018, 1-7.

[8]. HAWILA, M., CHIRAYATH, S., "Nuclear Security Risk Analysis: An Insider-Outsider Collusion Scenario," International Journal of Nuclear Security, Vol. 2, No. 2, 2016, Article 7.

[9]. HAWILA M., CHIRAYATH S., CHARLTON W., "Nuclear Security Risk Evaluation Using Adversary Pathway Analysis Methodology for an Insider-Outsider Collusion Scenario", 56 $6^{\text {th }}$ INMM Annual Meeting Proceedings, Indian Wells, USA, July 2015, 1-8.

[10]. MUDJIONO, DEWITA E., HASAN Y., "Rencana Program Protesi Fisik Reaktor Daya Eksperimental”, Prosiding Seminar Nasional Teknologi Energi Nuklir 2016, Batam, Indonesia Agustus 2016, 153-160.

[11]. The $26^{\text {th }}$ ITC on the Physical Protection of Nuclear Facilities and Materials. 2016. Hypothetical Facility Exercise Data: The Lone Pine Nuclear Power Plant. SNL. Albuquerque.

[12]. The $26^{\text {th }}$ ITC on the Physical Protection of Nuclear Facilities and Materials. 2016. Adversary Sequence Diagram (ASD) Model. SNL. Albuquerque.

[13]. The $26^{\text {th }}$ ITC on the Physical Protection of Nuclear Facilities and Materials. 2016. Path Interruption Analysis. SNL. Albuquerque.

[14]. The $26^{\text {th }}$ ITC on the Physical Protection of Nuclear Facilities and Materials. 2016. Multipath Analysis: Outsider Analysis with the Path Analysis (MP VEASI) Model. SNL. Albuquerque.

[15]. "Preventive and Protective Measures Against Insider Threats", IAEA, Vienna, Austria, Nuclear Security Series No. 8, 2008, 1-5 